\title{
HUBUNGAN PARITAS DENGAN PENGETAHUAN IBU NIFAS TENTANG PERAWATAN TALI PUSAT DI PUSKESMAS BAAMANG I SAMPIT TAHUN 2019
}

\section{(THE CORRELATION OF PARITY WITH KNOWLEDGE POSTPARTUM ABOUT THE UMBILICAL CORD OF CARE IN BAAMANG I PUBLIC HEALTH CENTER SAMPIT 2019)}

Norwidya Priansiska

Akademi Kebidanan Muhammadiyah Kotim

Email : wiwid.cia@gmail.com

\begin{abstract}
ABSTRAK
World Health Organization (WHO) menemukan jumlah kematian bayi sebesar 560.000, yang disebabkan oleh infeksi tali pusat. Pengetahuan ibu yang kurang dalam merawat tali pusat, menyebabkan ibu menggunakan obat tradisional sehingga memungkinkan berkembangnya clostridium tetani yang dapat menyebabkan infeksi pada neonatus hingga kematian bayi. Jenis penelitian analitik kuantitatif. Desain penelitian cross sectional. Jumlah responden sebagai sampel sebanyak 20 ibu nifas. Teknik pengambilan data dengan accidental sampling serta analisa data menggunakan analisis univariat dan analisis bivariat. Hasil analisis univariat menunjukkan bahwa mayoritas ibu dengan paritas Multipara sebanyak 10 orang (50 \%) , kemudian pengetahuan ibu mayoritas baik sebanyak 13orang (65\%). Dari analisis bivariat menunjukkan bahwa ada hubungan paritas dengan pengetahuan ibu nifas tentang perawatan tali pusat karena $\rho$ value $<0,05(\rho$ value $=0,034)$.
\end{abstract}

\section{Kata kunci : Paritas, Pengetahuan}

\begin{abstract}
The World Health Organization (WHO) found the number of infant deaths at 560,000 , which is caused by infection of the umbilicalcord. Mothers who lack knowledge in teating the cord, causing the mother to usetraditional medicine clostridium tetanithus enabling the development of which can cause to infant mortality a baby. Types of quantitative analytic research. Cross sectional research design. The total of respondents as a sample of 20 postpartum. Data collection technique with accidental sampling and data analysis using univariate analysis and bivariate analysis. The result of univariate analysis showed that the majority of parity correctly as much as 10 postpartum (50\%), then knowledge the majority correctly as much as 13 postpartum (65\%). From bivariate analysis shows that there is a relationship between parity with postpartum knowledge about the umbilical cord carebecause $\rho$ value $<0,05$ ( $\rho$ value $=0,034$ ).
\end{abstract}

\section{Keywords : Parity, Knowledge}

\section{PENDAHULUAN}

Word Health Organization menemukan angka kematian bayi sebesar 560.000 yang disebabkan oleh infeksi tali pusat. Di Asia
Tenggara Angka kematian bayi karena infeksi tali pusat sebesar 126.000 (WHO, 2010).

Angka kejadian infeksi pada bayi baru lahir di Indonesia berkisar antara $24 \%$ hingga 34\%, dan hal ini merupakan penyebab kematian yang 
kedua setelah Asfeksia Neonatorum yang berkisar antara 49\% hingga 60\% (Asiyah, 2017).

Angka kematian bayi di Kabupaten Kotawaringin Timur pada tahun 2015 sendiri mengalami peningkatan sebanyak 1 bayi dibanding tahun 2014 yaitu menjadi 10 - 11/1.000 kelahiran hidup, dan masih lebih rendah dibanding dengan target nasional sebesar 24/1.000 kelahiran (Dinkes Kotim, 2015).

Pada tahun 2017, dilaporkan terdapat 25 kasus dari 7 provinsi dengan jumlah meninggal 14 kasus atau sebesar 56\%. Jumlah kasus Tetanus Neonatorum pada tahun 2017 mengalami penurunan dari tahun sebelumnya, yang sebanyak 33 kasus pada tahun 2016. Meski demikian, AKB pada tahun 2017 mengalami peningkatan dari tahun sebelumnya yang sebesar $42,4 \%$. Jumlah kasus Tetanus Neonatorum terbanyak tersebar sama rata di tiga provinsi, yaitu Provinsi Riau, Banten, dan Kalimantan Barat. Provinsi dengan Case Fatality Rate (CFR) atau angka kematian $100 \%$ yaitu Provinsi Aceh, Kalimantan Tengah, dan Papua (Kemenkes RI, 2017).

Menurut Rusiana, S (2016), apabila ibu mempunyai anak semakin banyak atau lebih dari satu dan semakin tinggi tingkat pendidikan ibu, maka ibu akan lebih mengetahui tentang cara perawatan tali pusat bayi yang baik dan benar.

Berdasarkan studi pendahuluan yang dilakukan peneliti, pada tanggal 10 Mei 2019 ditemukan jumlah ibu nifas yang datang melakukan kunjungan nifas ke Puskesmas Baamang I sampit sebanyak 5 orang. Peneliti membagikan kuesioner kepada 5 orang ibu nifas. Hasilnya ditemukan bahwa dari 5 ibu nifas tersebut terdapat 2 ibu primipara (40\%), 2 ibu multipara (40\%) dan 1 ibu grandemultipara. Dari ke 5 ibu nifas tersebut, peneliti dapat menyimpulkan terdapat 3 orang ibu nifas (60\%) sudah mengetahui tentang perawatan tali pusat, yang terdiri dari 1 orang ibu primipara dan 2 orang ibu multipara, dan 2 orang ibu nifas (40\%) belum mengetahui tentang perawatan tali pusat, yang terdiri dari 1 orang ibu primipara dan 1 orang ibu grandemultipara.
Pada bulan Mei, seorang ibu primipara yang membawa bayinya ke Puskesmas Baamang I Sampit untuk melakukan kunjungan ulang neonatus mengatakan jika bayinya itu rewel dan demam, setelah dilakukan pemeriksaan ternyata tali pusat bayinya mengalami infeksi, yaitu keadaan tali pusatnya bernanah. Dikarenakan ibu tidak mengetahui cara perawatan tali pusat yang benar yaitu tidak mengganti kassa steril selama 3 hari yang mengakibatkan bayi demam.

\section{METODE PENELITIAN}

Jenis Penelitian yang digunakan adalah penelitian analitik dengan desain penelitian cross sectional, yang mana populasi nya yaitu semua ibu nifas yang datang sebagai pasien untuk melakukan kunjungan ulang pada masa nifas di Puskesmas Baamang I Sampit Tahun 2019. Pengambilan sampel menggunakan tehnik accidental sampling, Jadi sampel dalam penelitian ini yaitu 20 orang ibu nifas. Penelitian ini dilakukan di Puskesmas Baamang I Sampit pada bulan Maret - Juli 2019. Instrumen yang digunakan dalam penelitian ini yaitu kuisioner. Analisis data menggunakan 2 uji analisis yaitu analisis univariat dan bivariat (Uji Spearman Rank).

\section{HASIL DAN PEMBAHASAN}

Hasil penelitian yang didapatkan dari responden sebagai berikut :

1. Distribusi Frekuensi Paritas

Tabel 1

Distribusi Paritas Ibu Nifas

\begin{tabular}{llcc}
\hline No & Kriteria & Frekuensi (f) & Persentase(\%) \\
\hline 1 & Primipara (1) & 7 & $35 \%$ \\
2 & Multipara (2-4) & 10 & $50 \%$ \\
3 & $\begin{array}{l}\text { Grandemultipara } \\
\text { (>5) }\end{array}$ & 3 & $15 \%$ \\
\cline { 2 - 3 } & Jumlah & $\mathbf{2 0}$ & $\mathbf{1 0 0 \%}$ \\
\hline
\end{tabular}

Berdasarkan tabel 1 diatas dapat diketahui bahwa dari keseluruhan responden yang berjumlah 20 ibu nifas di Puskesmas Baamang I Sampit, menunjukkan bahwa mayoritas responden berdasarkan paritas pada 
ibu nifas adalah "Multipara" sejumlah 10 orang (50\%).

2. Distribusi Frekuensi Pengetahuan ibu nifas

Tabel 2

Distribusi Pengetahuan Ibu Nifas

\begin{tabular}{cccc}
\hline No & Kriteria & Frekuensi(f) & Persentase(\%) \\
\hline 1 & Baik $(76-100 \%)$ & 13 & $65 \%$ \\
2 & Cukup $(56-75 \%)$ & 5 & $25 \%$ \\
3 & Kurang $(<56 \%)$ & 2 & $10 \%$ \\
\hline & Jumlah & $\mathbf{2 0}$ & $\mathbf{1 0 0 \%}$ \\
\hline
\end{tabular}

Berdasarkan tabel 2 diatas dapat diketahui bahwa dari keseluruhan responden yang berjumlah 20 orang di Puskesmas Baamang I Sampit, menunjukkan bahwa mayoritas responden berdasarkan pengetahuan ibu nifas adalah "Baik" sejumlah 13 orang (65\%).

3. Tabulasi Silang Paritas dengan Pengetahuan Ibu Nifas Tentang Perawatan Tali Pusat

Tabel 3

Tabulasi Silang Paritas dengan Pengetahuan Ibu Nifas Tentang Perawatan Tali Pusat

\begin{tabular}{lccccccccc}
\hline \multicolumn{10}{c}{ Tingkat Pengetahuan } \\
\hline Paritas & \multicolumn{1}{c}{ Baik } & \multicolumn{1}{c}{ Cukup } & \multicolumn{2}{c}{ Kurang } & \multicolumn{2}{c}{ Total } \\
& $\mathrm{F}$ & $\%$ & $\mathrm{~F}$ & $\%$ & $\mathrm{~F}$ & $\%$ & $\mathrm{~F}$ & $\%$ \\
\hline Primipara & 2 & 15 & 3 & 60 & 2 & 10 & 7 & 35 \\
Multipara & 9 & 70 & 1 & 20 & 0 & 0 & 10 & 55 \\
Grande & 2 & 15 & 1 & 20 & 0 & 0 & 3 & 10 \\
multipara & & & & & & & & \\
\hline Total & $\mathbf{1 3 3}$ & $\mathbf{1 0 0}$ & $\mathbf{5}$ & $\mathbf{1 0 0}$ & $\mathbf{2}$ & $\mathbf{1 0 0}$ & $\mathbf{2 0}$ & $\mathbf{1 0 0}$ \\
\hline
\end{tabular}

Berdasarkan tabel 3 diatas dapat diketahui bahwa hasil dari tabulasi silang paritas dengan pengetahuan ibu nifas tentang perawatan tali pusat di Puskesmas Baamang I Sampit, menunjukkan dari keseluruhan responden yang berjumlah 20 orang ibu nifas yaitu dari 10 orang $(55 \%)$ ibu multipara, terdapat 9 orang $(70 \%)$ memiliki pengetahuan baik, 1 orang (20\%) memiliki pengetahuan cukup.
4. Hasil Uji Spearman Rank dengan SPSS

Tabel 4

Hasil Uji Spearman Rank dengan SPSS

\begin{tabular}{|c|c|c|c|c|}
\hline & & & $\begin{array}{l}\text { jumlah } \\
\text { paritas }\end{array}$ & $\begin{array}{l}\text { tingkat } \\
\text { pengetahua } \\
\text { n }\end{array}$ \\
\hline \multirow[t]{2}{*}{$\begin{array}{l}\text { Spearm } \\
\text { an's rho }\end{array}$} & Paritas & $\begin{array}{l}\text { Correlation } \\
\text { Coefficient } \\
\text { Sig. (2- } \\
\text { tailed) } \\
\mathrm{N}\end{array}$ & 20 & $\begin{array}{r}, 477^{\circ} \\
, 034 \\
20\end{array}$ \\
\hline & $\begin{array}{l}\text { Pengeta } \\
\text { uan }\end{array}$ & $\begin{array}{l}\text { Correlation } \\
\text { Coefficient } \\
\text { Sig. (2- } \\
\text { tailed) } \\
\text { N }\end{array}$ & $\begin{array}{r}, 477^{\star} \\
, 034 \\
20\end{array}$ & $\begin{array}{r}1,000 \\
. \\
20\end{array}$ \\
\hline
\end{tabular}

Berdasarkan tabel 4.6 hasil pengujian tersebut Output dari hasil uji Spearman Rank pada tingkat kepercayaan adalah $95 \%(\alpha=0,05)$. Jika $\rho$ value < a $(0,05)$, Ha diterima dan Ho ditolak yang berarti ada hubungan antara variabel independen dan variabel dependen, sig. (2-tailed) sebesar 0,034 atau kurang dari 0,05 sehingga diputuskan ada hubungan positif dan signifikan antara Paritas Dengan Pengetahuan lbu Nifas Tentang Perawatan Tali Pusat Di Puskesmas Baamang I Sampit Tahun 2019.

\section{PEMBAHASAN}

Sesuai dengan tujuan penelitian yang telah ditetapkan maka dalam bagian ini akan dibahas hasil penelitian yang telah dilaksanakan berdasarkan hasil yang telah disajikan.

1. Frekuensi Paritas

Hasil penelitian ini menunjukkan bahwa ibu nifas di Puskesmas Baamang I Sampit mayoritas ibu dengan paritas multipara yang artinya sudah memiliki anak antara 2-4 anak. Hal tersebut membuktikan juga bahwa ibu-ibu nifas mampu memahami dan bersedia melakukan perawatan tali pusat yang benar, yakni mampu meninggalkan cara tradisional dalam perawatan tali pusat bayi, dikarenakan jika ibu masih menggunakan cara tradisional dalam melakukan perawatan tali pusat maka akan terjadi infeksi pada tali pusat maupun disekeliling tali pusat bayi, bisa menyebabkan bayi demam bahkan hingga kejang sampai 
menyebabkan bayi meninggal. Dikarenakan ibu multipara sudah mempunyai pengalaman sebelumnya dalam merawat bayi dibandingkan ibu primipara maka dalam cara perawatan tali pusat bayi pun pasti bisa, apalagi jika melahirkan di tempat fasilitas kesehatan otomatis tenaga kesehatan pun akan memberitahu cara perawatan tali pusat yang baik dan benar.

\section{Frekuensi Pengetahuan}

Alasan kenapa mayoritas ibu nifas memiliki pengetahuan baik $(65 \%)$ tentang perawatan tali pusat sendiri dikarenakan sekarang sudah diberlakukan persalinan di fasilitas kesehatan, yang mana nantinya dari tenaga kesehatan khususnya bidan sendiri akan memberi tahu bahkan mengajari ibu nifas bagaimana cara melakukan perawatan tali pusat yang baik terlebih khususnya supaya terhindar dari infeksi, kemudian teknologi semakin canggih ibu nifas dapat memperoleh informasi dengan mudah dari internet mengenai cara perawatan bayi, yaitu cara merawat tali pusat, dan juga banyak yang sudah membuktikan dan belajar dari pengalaman sebelumnya banyak ibu nifas yang sudah tidak melakukan cara tradisional seperti member bumbu - bumbu dapur, dll untuk merawat tali pusat dikarenakan dapat menyebabkan infeksi pada tali pusat bayi bahkan bisa menyebabkan kematian pada bayi.

3. Hubungan Paritas dengan Pengetahuan

Analisis bivariat dengan Uji Spearman Rank. Berdasarkan tabel 4.6 dapat diketahui bahwa hasil penelitian uji statistik dengan menggunakan Uji Spearman Rank pada tingkat kemaknaannya adalah $95 \%(\alpha=0,05)$. Jika $\rho$ value < a $(0,05)$, Ho ditolak dan Ha diterima yang berarti ada hubungan antara variabel independen dan variabel dependen, sig. (2tailed) sebesar 0,034 atau lebih kecil dari 0,05 sehingga disimpulkan bahwa ada hubungan positif dan signifikan antara Paritas dengan Pengetahuan Ibu Nifas Tentang Perawatan Tali
Pusat Di Puskesmas Baamang I Sampit Tahun 2019.

Notoadmodjo (2012), yaitu pengetahuan sangat erat hubungannya dengan paritas karena semakin sering seseorang wanita melahirkan bayi dan merawatnya semakin banyak pengalaman pribadi yang diperoleh dan dapat menuntun seseorang dalam menarik kesimpulan.

Hasil penelitian diatas berbeda dengan penelitian yang dilakukan oleh Rusian, S (2016) yang berjudul "Hubungan Antara Paritas Dengan Tingkat Pengetahuan lbu Tentang Perawatan Tali Pusat Bayi di Ruang Annisa RS PKU Muhammadiyah Surakarta" yang menunjukan hasil bahwa dari 20 orang ibu nifas mayoritas dengan paritas (primipara dan multipara) dengan tingkat pengetahuan yang cukup tentang Perawatan Tali Pusat Bayi, sebanyak 5 responden (25\%).

Dari hasil penelitian ini, peneliti berasumsi apabila ibu yang pernah melahirkan bayi hidup atau mempunyai anak semakin banyak, maka ibu akan lebih mengetahui tentang cara perawatan tali pusat bayi yang baik dan benar. Berkaitan dengan hal tersebut sebenarnya ada beberapa faktor yang mempengaruhi pengetahuan seseorang itu menjadi baik, tetapi peneliti disini hanya meneliti tentang paritas saja. Hal ini dibuktikan misalnya dari faktor sumber informasi yang semakin mudah untuk dijangkau dari media massa dan juga dari tenaga kesehatan dan tidak sembarangan juga kita mengambil informasi dari media. Seperti misalnya ibu grandemultipara yang memiliki pengetahuan baik, dikarenakan sudah banyak pengalam untuk merawat anaknya sebelumnya. Meskipun pernah menggunakan cara tradisional dulunya yang didapatkan informasi dari orang tua maupun keluarga.

\section{KESIMPULAN}

Berdasarkan hasil penelitian Hubungan Paritas dengan Pengetahuan lbu Nifas Tentang Perawatan Tali Pusat di Puskesmas Baamang I 
Sampit, maka diperoleh kesimpulan sebagai berikut :

1. Frekuensi paritas pada ibu nifas di Puskesmas Baamang I Sampit Tahun 2019 mayoritas adalah multipara sejumlah 10 orang (50\%).

2. Frekuensi pengetahuan ibu nifas tentang perawatan tali pusat di Puskesmas Baamang I Sampit Tahun 2019, mayoritas adalah baik sejumlah 13 orang $(65 \%)$.

3. Frekuensi paritas berdasarkan pengetahuan ibu nifas tentang perawatan tali pusat di Puskesmas Baamang I Sampit Tahun 2019 adalah dari 10 orang (55\%) ibu multipara, terdapat 9 orang (70\%) memiliki pengetahuan baik, 1 orang (20\%) memiliki pengetahuan cukup

4. Terdapat hubungan yang signifikan dan positif antara Hubungan Paritas dengan Pengetahuan lbu Nifas Tentang Perawatan Tali Pusat di Puskesmas Baamang I Sampit yang ditunjukkan dengan nilai $\rho$ - value : 0,034 $<0,05$.

\section{DAFTAR PUSTAKA}

Antini, dkk. (2012). Asuhan Neonatus Bayi Dan Balita Untuk Keperawatan Dan Kebidanan, Cet 1. Jogjakarta: D-Medika.

Arikunto, Suharsimi. 2013. Prosedur Penelitian Suatu Pendekatan Praktik. Jakarta: PT RINEKA CIPTA.

Dinas Kesehatan Kotim. 2016. Profil Kesehatan Kotawaringin Timur 2015. http://www.dinkes.kotimkab.go.id diakses tanggal 23 April 2019.

Johariyah. 2012. Buku Ajaran Asuhan Kebidanan Persalinan Dan Bayi Baru Lahir. Cetakan 1. Jakarta: Cv. Trans info Media.

Hidayat, A. Aziz Alimul. 2014. Metode Penelitian Kebidanan dan Teknik Analisis Data. Edisi 2. Jakarta : Penerbilt Salemba Medika.

Kementerian Kesehatan RI. 2015. Profil Kesehatan Indonesia 2014. Jakarta : Kementerian Kesehatan Republik Indonesia.
Kementrian Kesehatan RI. 2017. Profil Kesehatan Indonesia 2017. Jakarta: Kementerian Kesehatan Republik Indonesia.

Marmi. 2015. Asuhan Kebidanan Pada lbu Nifas. Yogyakarta: Pustaka Pelajar

Maryam, R. Siti dkk. 2011. Mengenal Usia Lanjut dan perawatannya. Jakarta : Salemba Medik

Mubarak, W.I, 2015, IImu Kesehatan Masyarakat Teori dan Aplikasi. Jakarta: Salemba Medika.

Notoatmodjo, Soekidjo. 2012. Metodologi Penelitian Kesehatan. Jakarta : Penerbit Rineka Cipta

Nursalam. 2016. Metodologi Penelitian IImu Keperawatan: Pendekatan Praktis Edisi 4. Jakarta: Salemba Medika.

Riset Kesehatan Dasar 2013. Badan Penelitian Dan Pengembangan Kesehatan2013. Kemenerian Kesehatan RI. Riyanto, Agus. 2013. Aplikasi Metodologi Penelitian Kesehatan. Yogyakarta: Nuha Medika.

Rosita, Ayu . (2016). "Hubungan Paritas Dengan Perawatan Tali Pusat Pada Bayi Baru Lahir Oleh Ibu Postpartum Di Klinik Bersalin Hj. S. Tarigan Di Kota Pangkal Pinang". Diakses pada tanggal 23 Maret 2019

Rusiana, S. (2016). "Hubungan Paritas Dengan Tingkat Pengetahuan Ibu Tentang Perawatan Tali Pusat Bayi Di Ruang Annisa RS PKU Muhammadiyah Surakarta Tahun 2016". Diakses pada tanggal 23 Maret 2019.

Sulasmi, Sri. 2015. "Gambaran Tingkat Pengetahuan Ibu Tentang Perawatan Tali Pusat Pada Ibu Yang Melahirkan Di Rumah Sakit Panembahan Senopati Bantul Tahun 2015". Diakses Pada Tanggal 10 April 2019

Suliyono, Joko. 2012. 6 Hari Jago SPSS. Yogyakarta: Cakrawala

Tando, marie naomy. 2013. Asuhan Kebidanan Persalinan Dan Bayi Baru Lahir. Jil 1. Jakarta: In Media.

Varney, Helen. 2010. Buku Ajar Asuhan Kebidanan Edisi 4. Jakarta : EGC 